\title{
THE EFFECTS OF ATROPINE ON THE HEART RATE
}

\author{
Antonio Boba
}

\section{INTRODUCTION}

The PRESEnT Group of observations was initiated in the context of a larger effort to measure quantitatively the effects of drugs used for preanaesthetic medication. The assessment of the effects of any premedication is fraught with many difficulties which are not always obviated by the adoption of complicated "scoring" methods. However, atropine has one property which is readily amenable to precise quantitative measurement, and that is its cardio-accelerator effect. It was because of the possibility of reliable measurements that we have directed our efforts in that direction.

\section{Material and Methods}

Observations of the effects of atropine on the heart rate were carried out in 111 surgical patients divided into three groups of 37 each. Narcotics, barbiturates, antihistaminics or "no medication" were administered according to the following protocol.

\section{Group "A"}

Pentobarbitone $100 \mathrm{mg}$ and diphenhydramine $100 \mathrm{mg}$ were administered orally the evening preceding operation and again in the morning on the day of the operation, approximately two hours prior to the injection of atropine. Immediately before induction of anaesthesia, monitoring of the electrocardiogram was begun and the time elapsed between ten consecutive electrical systoles was measured. Atropine $0.6 \mathrm{mg}$ was then injected rapidly intravenously and two minutes later the time between ten consecutive electrical systoles was measured again. All measurements were made by means of a stopwatch accurate to $0.10 \mathrm{sec}$.

\section{Group " $B$ "}

These patients received no medication at bedtime or in the morning of the day of operation. Measurements of the heart rate before and after atropine, the dose of atropine and the time interval between measurements were the same as for Group "A".

\section{Group "C"}

These patients received pentobarbitone $100 \mathrm{mg}$ orally at bedtime and again approximately two hours before the atropine injection on the morning of the day of operation. In addition they were given also an intramuscular injection of $125 \mathrm{mg}$

From the Department of Anesthesia, The Southern Illinois Clinic, Ltd., 1 Doctors' Park Road, Mount Vemon, Ill. 62864. 
TABLE I

\begin{tabular}{|c|c|c|c|}
\hline & $\begin{array}{c}\text { Group "A" } \\
(\mathrm{N}+\mathrm{B})\end{array}$ & $\begin{array}{l}\text { Group "B" } \\
\text { (NPO) }\end{array}$ & $\begin{array}{c}\text { Group "C"' } \\
(\mathrm{N}+\mathrm{D})\end{array}$ \\
\hline $\begin{array}{l}\text { Patient's age (years) } \\
\text { range } \\
\text { mean } \\
\text { standard deviation }\end{array}$ & $\begin{array}{l}16-57 \\
33.6 \\
10.7\end{array}$ & $\begin{array}{l}17-59 \\
33.9 \\
11.0\end{array}$ & $\begin{array}{l}15-58 \\
31.0 \\
11.6\end{array}$ \\
\hline $\begin{array}{l}\text { Patient's weight }(\mathrm{Kg}) \\
\text { range } \\
\text { mean } \\
\text { standard deviation }\end{array}$ & $\begin{array}{c}46-123 \\
69.9 \\
18.8\end{array}$ & $\begin{array}{c}44-119 \\
66.0 \\
16.4\end{array}$ & $\begin{array}{c}41-115 \\
71.1 \\
17.0\end{array}$ \\
\hline $\begin{array}{l}\text { 'time' before atropine } \\
\text { range } \\
\text { mean } \\
\text { standard deviation }\end{array}$ & $\begin{array}{c}4.8-10.5 \\
7.5 \\
1.4\end{array}$ & $\begin{array}{c}\text { 5. } 2-11.6 \\
7.9 \\
1.7\end{array}$ & $\begin{array}{c}5.5-12.2 \\
8.2 \\
1.5\end{array}$ \\
\hline $\begin{array}{l}\text { 'time' after atropine } \\
\text { range } \\
\text { mean } \\
\text { standard deviation }\end{array}$ & $\begin{array}{c}4.0-8.6 \\
6.0 \\
1.1\end{array}$ & $\begin{array}{c}4.5-11.0 \\
6.2 \\
1.4\end{array}$ & $\begin{array}{c}3.6-8.6 \\
6.3 \\
1.2\end{array}$ \\
\hline $\begin{array}{l}\text { 'time' after atropine as \% of } \\
\text { 'time' before atropine } \\
\text { range } \\
\text { mean } \\
\text { standard deviation }\end{array}$ & $\begin{array}{c}57-104 \\
80 \\
11\end{array}$ & $\begin{array}{c}52-103 \\
80 \\
13\end{array}$ & $\begin{array}{c}53-100 \\
77 \\
12\end{array}$ \\
\hline $\begin{array}{l}\text { Atropine dose }(\mathrm{mgm} / \mathrm{Kg}) \times 100 \\
\text { range } \\
\text { mean } \\
\text { standard deviation }\end{array}$ & $\begin{array}{l}0.49-1.30 \\
0.91 \\
0.20\end{array}$ & $\begin{array}{c}0.50-1.36 \\
0.96 \\
0.21\end{array}$ & $\begin{array}{l}0.52-1.10 \\
0.83 \\
0.21\end{array}$ \\
\hline
\end{tabular}

Group identification. Group "A" $(\mathrm{N}+\mathrm{B})$; these patients received pentobarbitone and diphenhydramine before atropine. Group " $B$ "; these patients received no premedications. Group " $C$ "; these patients received pentobarbitone and meperidine before atropine (see text for details relative to timing and routes of administration).

NoTE: "time" is the time elapsed between ten consecutive electrical systoles, measured in seconds.
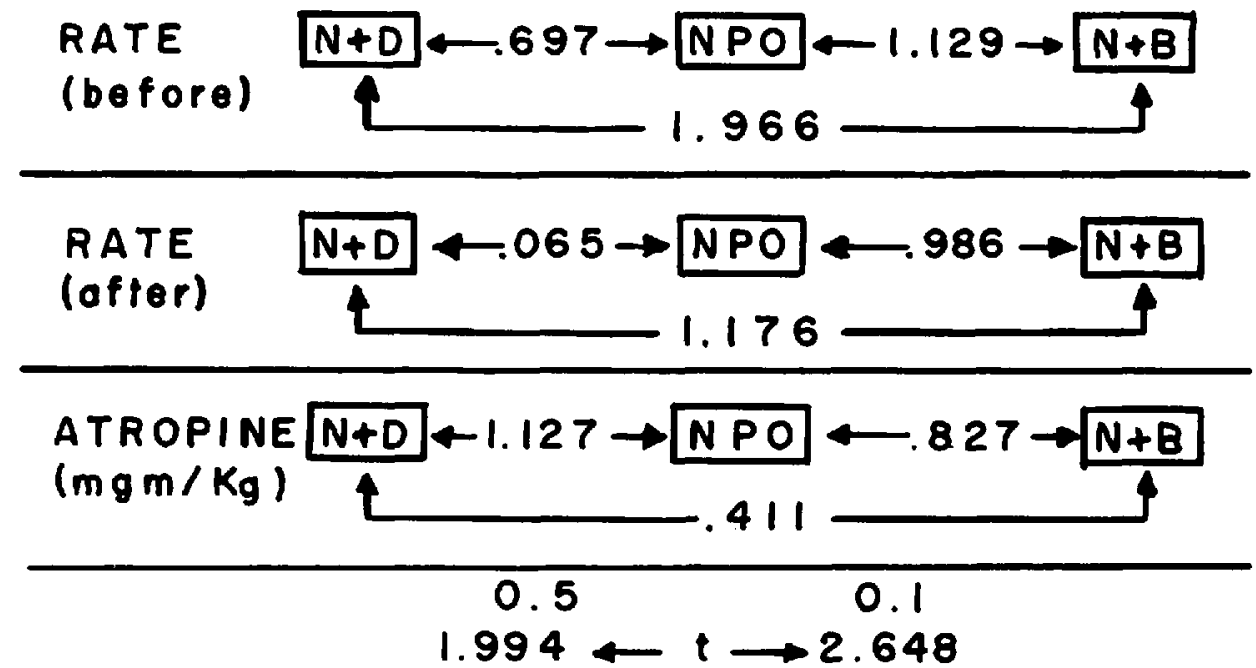

Figure 1. Results obtained when matching the results for the various groups and then calculating $t$ values for each match. Bottom; $t$ values for the 5.0 per cent and 1.0 per cent confidence limits for 72 degrees of freedom. (Group identification; $N+B=$ Group "A", NPO = Group "B", $N+D=$ Group “C"). 


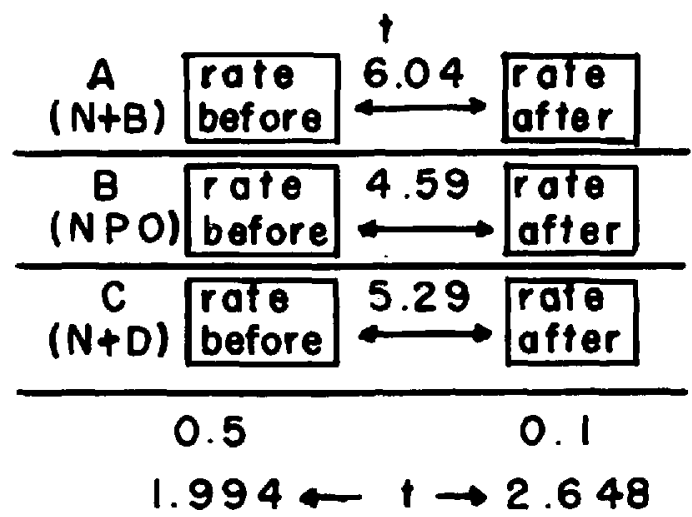

Ficure 2. Results obtained when matching for each patient and for each group the pulse rate measured before and after atropine and calculating $t$ values for each match. Bottom; $t$ values for the 5.0 per cent and 1.0 per cent confidence limits and for 72 degrees of freedom. Group identificaton; same as in text.

meperidine at the time of the second dose of pentobarbitone. Measurements of the heart rate before and after atropine, the dose of atropine and the interval between measurements were the same as for Group " $A$ ".

\section{Results}

Statistical condensations of data are given in Table I and Figure $1 .^{\circ}$

The actual "datum" under consideration is the time elapsed between ten consecutive electrical systoles: thus the higher the pulse rate the shorter the elapsed time and vice versa. The real advantage of this approach rests in the fact that conversion to "heart rate" would tend to magnify time reading errors for the slower rates and minimize such errors for the faster rates.

The basic heart rate varies in the three groups, presumably in response to the particular premedication chosen (Table I and Figure 1). The intravenous administration of atropine results in a very significant increase in heart rate for all patients in all groups (Figure 2). Nevertheless, the mean pulse rate after atropine maintains the same relationships between all groups as it did before atropine. In other words, the fastest mean heart rate is still found in the pentobarbitone/ diphenhydramine treated group and the slowest mean heart rate in the pentobarbitone/meperidine treated group. However, after atropine these differences are minimal and it can be said that, with reference to the heart rate, the intravenous administration of atropine has probably reduced the three populations to a single one (Figure 1).

Table I shows that those patients who were pretreated with the pentobarbitone/ meperidine combination received on the average and on a weight-adjusted basis a lesser amount of atropine than patients in the other groups. However, the table also shows that the patients in that same group demonstrated the greatest increases

-A complete and detailed tabulation of the data developed in the course of these observations can be obtained, free of charge, by writing directly to the author. 
$C(N+D)$
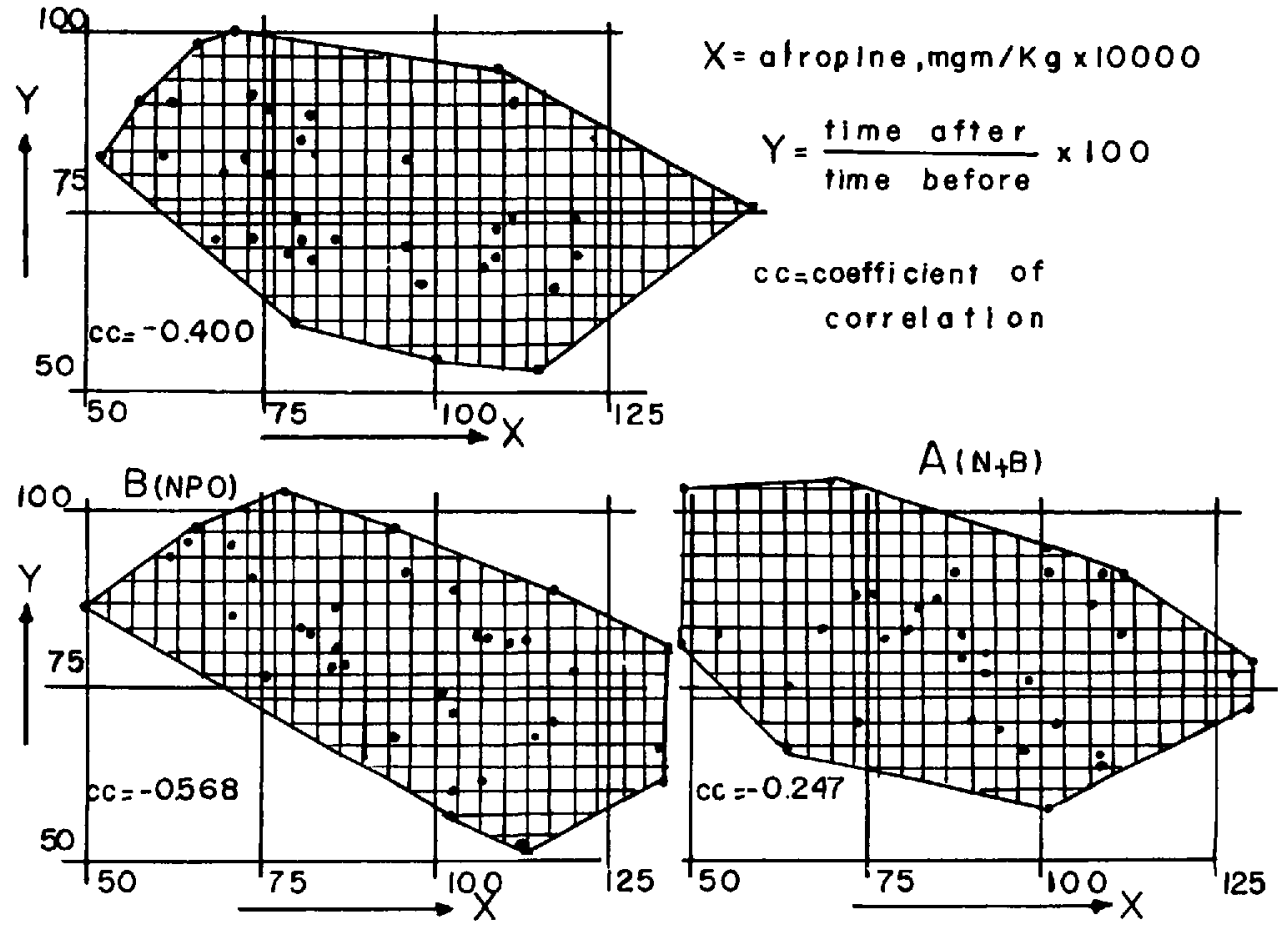

Figure 3. Results of plotting the increase in heart rate after atropine calculated as a percentage of baseline values, against the weight adjusted dose of atropine for each patient and for each group. Notice the poor correlation coefficients and the wide scatter of the data,

in heart rate. In order to elucidate this point the cardiac accelerating effect of atropine $0.6 \mathrm{mg}$ was plotted against the weight-adjusted dose of atropine for each patient and for each group. ${ }^{\circ}$ As Figure 3 shows, the poor correlation between atropine dose and increase of heart rate is a constant and common feature. The same method of matching pairs of values was then extended to determine whether correlation exists between any of the variables measured. It was then established that the best correlation existed between the baseline heart rate and the rate after atropine injection, irrespective of any concomitant drug administration (Figure 4).

\section{DisCussion}

Ideally, the administration of any drug should fulfill the following criteria:

(1) the drug should be capable of producing one, and only one, effect;

(2) the drug should be administered in an amount sufficient to induce a quantitatively measurable response;

(3) it should be possible quantitatively to monitor the effects of the drug.

-The cardiac accelerating effect of atropine was defined and computed as follows:

("time" after/ "time" before) $\times 100$

where "time" is the time elapsed between ten consecutive electrical systoles. 


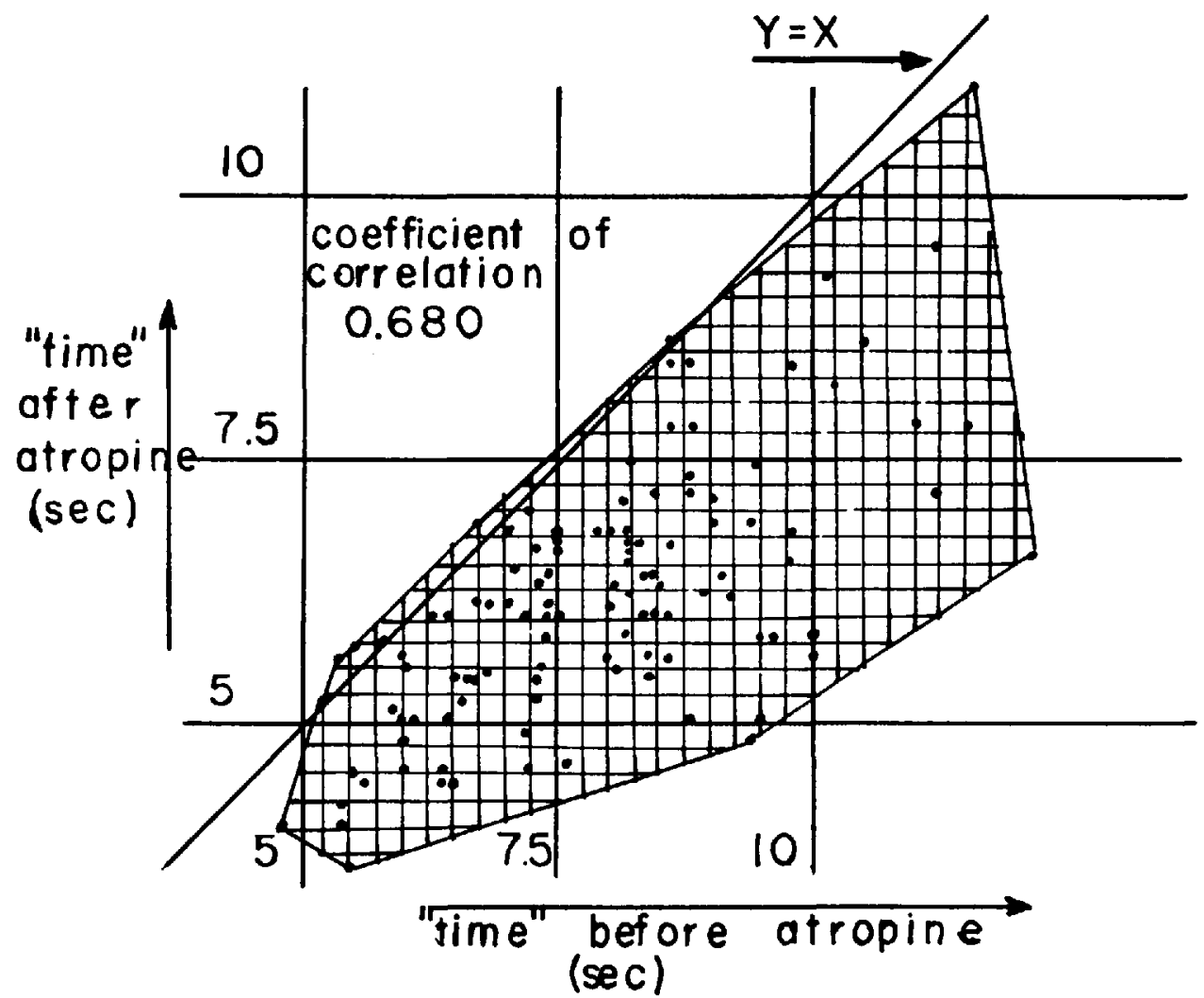

Figune 4. Results of plotting the heart rate before atropine against the heart rate after atropine (in reality the time elapsed between ten consecutive electrical systoles). Notice the good correlation coefficient. The graph indicates that the slowest hearts are the ones that are accelerated the most irrelevant of any concomitant premedication routine.

Reviewing the pharmacology of atropine as well as the data discussed above it must be concluded that the established practice of administering an intramuscular injection of atropine about 90 minutes prior to anaesthesia does not satisfy any of these criteria.

As for the first requirement, while the cardio-accelerator response to atropine can readily be measured, the drug exerts many other effects, most of which are not amenable to precise measurement. While the second criterion could be satisfied, rather larger doses than commonly accepted would have to be administered to increase the pulse rate significantly if the intramuscular route was employed.

Finally, considering the third requirement it is impractical to measure the pulse rate accurately at precisely stated intervals before and after atropine. The notion that one could individualize the dose of atropine and predict its effects, thereby obviating the need for repeated pulse rate measurements, is not sound. In fact, as Figure 3 shows, there is very poor correlation between the weight-adjusted dose of atropine and its accelerating effects. One should also note that the effects of any other drug administered as a part of the premedication package are equally unpredictable. In this connection one should consider Table II which shows data 
TABLE II

\begin{tabular}{lcccc}
\hline \hline Patient & Age & $\begin{array}{c}\text { "Time" } \\
\text { Before }\end{array}$ & $\begin{array}{c}\text { "Time" } \\
\text { after }\end{array}$ & Group \\
\hline J.M. & 40 & 11.6 & 11.0 & B (NPO) \\
M.G. & 23 & 8.6 & 8.6 & C (N + D) \\
& 27 & 9.4 & 4.8 & B (NPO) \\
L.M. & 7.4 & 7.6 & 4.6 & C (N + D) \\
& & 7.3 & 6.6 & B (NPO) \\
M.J. & 34 & 7.5 & 6.0 & A (N + B) \\
& & 7.5 & 6.6 & C (N + D) \\
\hline
\end{tabular}

Data from four patients that were observed twice during the period of study. Notice that contrary to predictions that could have been made from Table I, patients J.M. and M.G. exhibited faster baseline heart rates after receiving the pentobarbitone/me peridine combination than after receiving no premedication. Patient M.J. exhibited the same baseline heart rate irrelevant of premedication routine. Notice, for each patient, the widely different rates of heart rate increase even though the atropine dose was consistently the same (both absolute and weight adjusted). (Group identification, same as in Table I).

from four patients who were admitted to the study twice. Considering Table I, one would have predicted that when premedicated with the pentobarbitone/meperidine combination the patients would have exhibited slower heart rates than when premedicated with the pentobarbitone/diphenhydramine combination or when receiving no premedication at all. However, the predicted pattern did not in fact materialize in three out of four patients.

In conclusion it would appear that while atropine increases the heart rate its effect is not consistently predictable from a quantitative viewpoint, even if it is administered on a weight-adjusted basis. It would appear that, if atropine is to be used, then the best method of administration would be intravenous injection of fractional increments until some clearly predetermined goal is achieved. One such goal might be defined as "an increase in heart rate of at least 25 per cent over baseline," and another might be "the establishment of a heart rate of not less than 88 beats per minute." The basis upon which the selection of such a goal would ultimately rest is not very clear and one should be prepared to accept the possibility that there is no simple way of establishing in advance either the dose of atropine to be administered or the end point to be attained.

\section{SUMMARY}

The cardiac-accelerating effects of $0.6 \mathrm{mgm}$ of atropine administered intravenously were tested in 111 patients (three groups of 37 patients each). The patients in Group " $A$ " received pentobarbitone and diphenhydramine orally before the atropine injection; those in Group " $B$ " received no medications and those in Group " $\mathrm{C}$ " received pentobarbitone orally and meperidine intramuscularly. For the purpose of greater precision the time elapsed between ten consecutive electrical systoles was taken as the measure of the heart rate. Measurements were carried out before and two minutes after atropine injection.

The control mean heart rate was slower in Group " $\mathrm{C}$ " and faster in Group " $\mathrm{A}$ ". Atropine increased the heart rate of all patients, most of those in Group " $\mathrm{C}$ " and 
least of those in Group " $\mathrm{A}$ " and in such a manner that, after atropine, the means for the three groups were nearly identical.

There is very poor correlation between the weight-adjusted dose and the cardiac accelerating effects of $0.6 \mathrm{mg}$ atropine administered intravenously. The highest correlation coefficient $(0.680)$ is found between the heart rate before and after atropine; i.e., the slower hearts are those that accelerated the most and the fastest hearts accelerated the least, irrespective of weight-adjusted dose or concomitant premedication routine.

\section{RÉsumé}

Les effets d'une dose de $0.6 \mathrm{mg}$ d'Atropine sur la fréquence cardiaque ont fait l'objet d'une étude chez 111 patients répartis en trois groupes de 37 sujets. Pour fins de mesures et de comparaison dans ce travail, on a défini la fréquence comme la durée de dix systoles électriques consécutives.

Les malades du premier groupe (A) ont reçu $100 \mathrm{mg}$ de Pentobarbital et $100 \mathrm{mg}$ de Diphrenhydramine par la bouche deux heures avant l'injection d'Atropine; ceux du groupe $\mathrm{B}$ n'ont pas reçu de prémédication; enfin, les patients du Groupe $\mathrm{C}$ ont reçu $100 \mathrm{mg}$ de Pentobarbital et $125 \mathrm{mg}$ de Meperidine par voie intramusculaire deux heures avant l'injection d'Atropine. On a calculé la fréquence immédiatement avant l'injection d'Atropine et deux minutes après son injection par voie intraveineuse.

En mesurant, comme mentionné plus haut, la durée de 10 systoles électriques consécutives, on a obtenu les résultats moyens suivants. Groupe A: avant Atropine: $7.5 \mathrm{sec}$. (déviation standard 1.4); après Atropine: $6 \mathrm{sec}$. (1.1). Groupe B: avant Atropine: $7.9 \mathrm{sec}$. (1.7); après: $6.2 \mathrm{sec}$. (1.4). Groupe C: avant: $8.2 \mathrm{sec}$. (1.5); après: 6.3 sec. (1.2).

L'on a établi la relation entre la dose d'Atropine $(0.6 \mathrm{mg})$ et la poids des patients chez les malades du groupe $C$ et l'on a réalisé que les malades qui ont reçu la plus petite dose d'Atropine (en fonction du poids) ont démontré la plus grande accélération de fréquence. Sur la base de cette observation l'on a établi un graphique tenant compte du pourcentage d'accélération de fréquence et de la dose d'Atropine en fonction du poids, et ceci pour tous les sujets de l'étude. Sur la base de ce graphique il n'y a pas de bonne corrélation.

Finalement, le pourcentage d'accélération de la fréquence après Atropine a été inscrit sur un graphique en fonction de la fréquence cardiaque avant Atropine. L'on obtient de cette façon le plus haut coéfficient de corrélation $(+0.680)$.

L'auteur conclut que les effets de l'Atropine sur la fréquence cardiaque sont difficiles à prédire et conseille d'administrer cet agent en petites doses répétées jusqu’à ce que l'effet désiré soit obtenu.

$\begin{array}{ll}\text { Generic and Brand Names of Drugs } \\ \text { Pentobarbitone } & \text { Nembutal } \\ \text { Diphenhydramine } & \text { Benadry }^{\circledR} \\ \text { Meperidine } & \text { Demerol } \\ \text { Thiopentone } & \text { Pentothal }^{\circledR}\end{array}$

